\title{
Thermal synthesis and structural characterization of the orthorhombic $\mathrm{Th}_{2}\left(\mathrm{PO}_{4}\right)\left(\mathrm{P}_{3} \mathrm{O}_{10}\right)$
}

\author{
Jorge GARCIA-GLEZ ${ }^{1}$, Belén F. ALFONSO ${ }^{1}$, José A. HUIDOBRO ${ }^{1}$, \\ Sergei A. KHAINAKOV ${ }^{2}$, Germán R. CASTRO ${ }^{3}$, Camino TROBAJO ${ }^{1}$ \\ ${ }^{1}$ Departamentos de Física, Matemáticas y Química Orgánica e Inorgánica, \\ Universidad de Oviedo-CINN, 33006 Oviedo, Spain \\ ${ }^{2}$ Servicios Científico-Técnicos, Universidad de Oviedo, 33006 Oviedo, Spain \\ ${ }^{3}$ SpLine Spanish CRG Beamline at the ESRF, Grenoble cedex ESRF-BP 220-38043, France
}

The immobilization in ceramic materials for an underground repository can be considered one of the options for the management of long-lived and highly active radionuclides. In this field, our research group reported both the synthesis and structural characterization of the first innertransition metal monohydrogenphosphate, $\mathrm{Th}\left(\mathrm{HPO}_{4}\right)_{2} \cdot \mathrm{H}_{2} \mathrm{O}$ [1].

The experimental procedure (hydrothermal synthesis with $\mathrm{H}_{3} \mathrm{PO}_{3}$ as the source of phosphorus) was similar to that we used previously in the well crystallized $\mathrm{Th}_{2}\left(\mathrm{PO}_{4}\right)_{2}\left(\mathrm{HPO}_{4}\right) \cdot \mathrm{H}_{2} \mathrm{O}$ preparation [2], which is the precursor (by thermal treatment) of $\beta-\mathrm{Th}_{4}\left(\mathrm{PO}_{4}\right)_{4} \mathrm{P}_{2} \mathrm{O}_{7}$. This material is a promising ceramic for the specific immobilization of tetravalent actinides, as it allows the incorporation of large amounts of uranium, neptunium or plutonium by substitution of thorium in its crystal structure and it exhibits a valuable sintering capability and an interesting long term behavior (including resistance to dissolution and/or irradiation). In addition, by using a very simple experimental strategy, we reported the synthesis of the first ammonium-thorium phosphates, $\left(\mathrm{NH}_{4}\right)_{2} \mathrm{Th}\left(\mathrm{PO}_{4}\right)_{2} \cdot \mathrm{H}_{2} \mathrm{O}$ and $\mathrm{NH}_{4} \mathrm{Th}_{2}\left(\mathrm{PO}_{4}\right)_{3}$, which were structurally described [3]. The structure of $\mathrm{NH}_{4} \mathrm{Th}_{2}\left(\mathrm{PO}_{4}\right)_{3}$ is similar to their alkaline analogues $\mathrm{M}^{\mathrm{I}} \mathrm{M}^{\mathrm{IV}}{ }_{2}\left(\mathrm{PO}_{4}\right)_{3}\left(\mathrm{M}^{\mathrm{I}}=\mathrm{Li}, \mathrm{Na}, \mathrm{K}, \mathrm{Rb}, \mathrm{Cs} ; \mathrm{M}^{\mathrm{IV}}=\right.$ $\mathrm{Th}, \mathrm{U}, \mathrm{Np}, \mathrm{Pu}$ ). It is built with $\mathrm{PO}_{4}$ monophosphate groups and $\mathrm{ThO}_{9}$ polyhedra sharing their apices and their edges, thereby forming a three dimensional framework. This is a different structure to the adopted by the $\mathrm{Th}_{1 / 4} \mathrm{Zr}_{2}\left(\mathrm{PO}_{4}\right)_{3}$ (NZP-structural family, NASICON-type) in which the extraframework thorium(IV) is hexacoordinated [4].

This contribution reports both the thermal synthesis and the crystal structure of $\beta-\mathrm{ThP}_{2} \mathrm{O}_{7}$, obtained from $\left(\mathrm{NH}_{4}\right)_{2} \mathrm{Th}\left(\mathrm{PO}_{4}\right)_{2} \cdot \mathrm{H}_{2} \mathrm{O}$ as precursor. $\beta-\mathrm{ThP}_{2} \mathrm{O}_{7}$ is isostructural to $\beta-\mathrm{UP}_{2} \mathrm{O}_{7}$, and crystallizes in the orthorhombic space group $P n 2_{1} a(a=11.6846(2) \AA, b=7.1746(1) \AA$, $c=12.9320(3) \AA, Z=4)$. Its structure has been refined from synchrotron $\mathrm{X}$-ray powder diffraction data. $\mathrm{ThO}_{8}$ polyhedral chains along the $b$-axis coexist with both $\mathrm{PO}_{4}{ }^{3-}$ and $\mathrm{P}_{3} \mathrm{O}_{10}{ }^{5-}$ groups, leading to the formula $\mathrm{Th}_{2}\left(\mathrm{PO}_{4}\right)\left(\mathrm{P}_{3} \mathrm{O}_{10}\right)$.

[1] M.A. Salvadó, P. Pertierra, G.R. Castro, C. Trobajo, J.R. García, Inorg. Chem., 47 (2008) 1246 (and references therein)

[2] M.A. Salvadó, P. Pertierra, A.I. Bortun, C. Trobajo, J.R. García, Inorg. Chem., 44 (2005) 3512

[3] M.A. Salvadó, P. Pertierra, A.I. Bortun, C. Trobajo, J.R. García, Inorg. Chem., 47 (2008) 7207 (and references therein)

[4] A.I. Orlova, V.Yu. Volgutov, G.R. Castro, S. García-Granda, S.A. Khainakov, J.R. García, Inorg. Chem., 48 (2009) 9046 